\title{
Efficient long-term conservation of Taraxacum pieninicum synthetic seeds in slow growth conditions
}

\author{
Monika Kamińska $^{1} \cdot$ Marcin Gołębiewski $^{1,2} \cdot$ Andrzej Tretyn $^{1,2} \cdot$ Alina Trejgell $^{1,2}$
}

Received: 14 July 2017 / Accepted: 2 November 2017 / Published online: 17 November 2017

(c) The Author(s) 2017. This article is an open access publication

\begin{abstract}
The aim of this paper was to develop a protocol for efficient storage of artificial seeds of Taraxacum pieninicum, critically endangered Asteraceae species. Storage under reduced light conditions or in the darkness was tested on a basis of synthetic seeds ability to conversion and post-storage regrowth of shoot tips. The results indicated that synseeds obtained from shoot tips of T. pieninicum can be stored at $4{ }^{\circ} \mathrm{C}$ even for 12 months without subculture. The light is a stress factor during storage what was manifested by numerous necrosis and decreased shoots ability to proliferate in optimal growth conditions in 1st subculture. Additionally our results showed that the storage does not produce genetic variation at the resolution provided by the flow cytometry and RAPD analysis.
\end{abstract}

Keywords Flow cytometry $\cdot$ RAPD $\cdot$ Cold-storage $\cdot$ Light stress $\cdot$ Synthetic seed $\cdot$ Taraxacum pieninicum

\section{Introduction}

The world's biodiversity is declining at an unprecedented rate every year. Over 5000 of plant species are listed as critically endangered (IUCN 2017). Conservation in the field shows major drawbacks (e.g. requirement of a large amount of area, exposure to disease or herbivores attack), which limit its efficacy and threaten the safety of plant genetic resources conserved in this way (Engelmann 2011). In vitro technique enables efficient short- or long-term storage, especially useful for the biodiversity protection by conservation of endangered species genome. However, in vitro micropropagation needs subcultures after each 4 weeks fraught with the risk of contamination and loss of culture. Slow growth procedures allow plant conservation without passages even for few years, depending on the species (Cruz-Cruz et al. 2013).

Communicated by Marcos V. Meiado.

Alina Trejgell

trejgell@umk.pl

1 Chair of Plant Physiology and Biotechnology, Nicolaus Copernicus University, Toruń, Poland

2 Centre for Modern Interdisciplinary Research, Nicolaus Copernicus University, Toruń, Poland
The synthetic seed technology is designed to combine the advantages of clonal propagation with those of seed propagation and storage. Synthetic seeds are defined as artificially encapsulated plant tissue that can be used for sowing as a seed and that possess the ability to convert into a whole plant under in vitro conditions, and that retain this potential also after storage (Ara et al. 1999). Combinations of sodium alginate and calcium chloride concentrations result in a synseeds with different texture, shape and transparency. The alginate coating behaves like an artificial endosperm, which enables uptake of nutrients to the explant during re-growth in optimal conditions (Ahmed et al. 2015).

In spite of many advantages, culture in vitro may be associated with variation among obtained plants, named somaclonal variation. It is a random phenomenon, which can affect any region of the genome and can be exhibited at various levels, including phenotypical, cytological, biochemical and genetic/epigenetic (Krishna et al. 2016). Detection and characterization of somaclonal variants is carried out by analyzing the morphology of plants (Pérez et al. 2011), the structure and number of chromosomes (Currais et al. 2013), the profile of protein (Yaacob et al. 2013) or DNA content of the cells (Jin et al. 2008). It is assumed that factor affecting cell cycle may increase the probability of somaclonal variation. Physical parameters (temperature, light intensity, photoperiod) and chemical agents (plant hormones, mainly cytokines and some osmoprotectants) are capable of causing 
a somaclonal variation. However, the most common factors affecting somaclonal variation are genotype, explant source and period of in vitro culture (Bordallo et al. 2004).

Taraxacum pieninicum Pawł. is probably the oldest endemic plant occurring in the Pieniny Mountains (Poland). This species is one of the Asteraceae family members, the largest family of flowering plants in the world. Karyological research have shown that this species has a diploid $(2 n=16)$ set of chromosomes (Małecka 1961). T. pieninicum reproduces sexually but it is also capable of vegetative reproduction (Kula et al. 2013). Factors such as a small number of individuals and limited seeds germination due to the feeding of invertebrates, in particular snails, are a threat to the survival of this species. In addition, the seeds of Taraxacum species are difficult to store because germination of seeds occurs immediately after maturation and seeds lose their vitality significantly after 2 years of storage (Tas and Van Dijk 1999; Honek et al. 2005).

In the previous studies the protocol for efficient in vitro multiplication and procedure for shoot tips storage of this species at $10{ }^{\circ} \mathrm{C}$ were developed (Trejgell et al. 2013; Kamińska et al. 2016) However, despite the low storage temperature, shoot growth has not been sufficiently inhibited, which has negatively affected the quality of the stored material. The aim of the current study was to inhibit $T$. pieninicum shoots growth by lowering the temperature to $4{ }^{\circ} \mathrm{C}$ and to limit damage of meristem through alginate-encapsulation of the shoot tips. Assessment of ploidy stability and clonal fidelity of the plants stored and converted from synseeds has been attempted using flow cytometry and RAPD.

\section{Materials and methods}

\section{Plant material and culture conditions}

The study was carried out on the T. pieninicum microshoots, which were obtained from axillary buds on shoot tips. Shoot tips were subcultured every 4 weeks on basal MS medium supplemented with $3 \%$ sucrose, $1.11 \mu \mathrm{M}$ BA, $0.14 \mu \mathrm{M}$ NAA and $0.8 \%$ agar. The $\mathrm{pH}$ of the medium was adjusted to 5.8 before autoclaving. Cultures were incubated in continuous white fluorescent light $\left(80 \mu \mathrm{mol} \cdot \mathrm{m}^{-2} \cdot \mathrm{s}^{-1}\right)$ at $26 \pm 1{ }^{\circ} \mathrm{C}$ (optimal growth conditions described by Trejgell et al. 2013).

\section{Encapsulation of explants}

Microshoots ( $4 \pm 1 \mathrm{~mm}$ long) were aseptically excised from the shoots cluster (Fig. 1a) and their leaf blades were removed. The shoot tips were then coated with 3\% sodium alginate (Sigma-Aldrich) prepared in liquid MS medium. Encapsulation was accomplished by dropping the explants individually into sterile $100 \mathrm{mM} \mathrm{CaCl} 2 \cdot 2 \mathrm{H}_{2} \mathrm{O}$ (Duchefa
Biochemie) solution using a pipette and polymerized for $25 \mathrm{~min}$. Encapsulated shoot tips were retrieved from the calcium chloride solution using sterile sieve, washed with sterile distilled water and dried on a sterile filter (Fig. 1b).

\section{Cold-storage conditions}

The synthetic seeds were transferred into Magenta ${ }^{\circledR}$ box containing $50 \mathrm{ml}$ MS medium supplemented with $3 \%$ sucrose, $0.8 \%$ agar, without plant growth regulators and stored under continuous white fluorescent light $\left(40 \mu \mathrm{mol} \cdot \mathrm{m}^{-2} \cdot \mathrm{s}^{-1}\right)$ or in darkness at $4 \pm 1{ }^{\circ} \mathrm{C}$ for $3,6,9$ and 12 months. Non-stored synthetic seeds were used as control.

\section{Post-storage regrowth}

Synthetic seeds converted into plantlets during cold-storage. The visual rating of the stored shoots was evaluated directly after cold treatment. Shoots were rated on the scale from 0 to 5 , on the basis of plant appearance (modified scale from Reed 1992, for details see Trejgell et al. 2015). Shoot tips from converted plants were transferred on fresh MS medium with full-strength nutrients supplemented with $3 \%$ sucrose, $1.11 \mu \mathrm{M} \mathrm{BA}, 0.14 \mu \mathrm{M}$ NAA and $0.8 \%$ agar in optimal growth conditions and subcultured twice. The survival rate (the number of shoots which visually did not exhibit complete necrosis after cold-storage and were able to conversion per one repetition) and proliferation rate (number of shoots per explant) were evaluated after 4-week subculture.

For acclimatization the obtained shoots were transferred onto rooting medium (MS without plant hormones). Ability of shoots to root was analyzed on the base of number of roots per shoot after 4 weeks, whereupon plantlets were removed from the Magenta ${ }^{\circledR}$ boxes, washed gently with sterile water, transferred to plastic pots containing a sterile mixture of vermiculite and sand $(1: 1 \mathrm{v} / \mathrm{v})$, and covered with transparent boxes to maintain humidity (60-70\%). After 8 weeks the plantlets were transferred to field conditions.

\section{Flow cytometry analysis}

Ploidy level of plantlets after acclimatization to field conditions was evaluated using flow cytometry. Young plants leaves of each variant were placed in a glass Petri dish $(10-15 \mathrm{mg})$ and lysis buffer $(45 \mathrm{mM} \mathrm{MgCl}, 30 \mathrm{mM}$ sodium citrate, $20 \mathrm{mM}$ 4-morpholinepropane sulphonic acidMOPS, $0.1 \%$ Triton X-100 in distilled water, pH 7.0) (Galbraith et al. 1983) was added to the plant material. The tissue was chopped with a razor blade to release nuclei. Individual samples were then filtered to remove debris with a pre-separation filter $30 \mu \mathrm{m}$ nylon mesh (Miltenyi Biotec $\mathrm{GmbH}$, Germany) into $5 \mathrm{ml}$ tubes. The nuclei suspension $(1.5 \mathrm{ml})$ was stained with $30 \mu \mathrm{l}$ of a $2 \%$ propidium iodide (PI) solution. 
Fig. 1 In vitro storage of encapsulated shoot tips of Taraxacum pieninicum: initial material before storage (a), synthetic seeds (b), shoots converted during 12 months of storage at $4{ }^{\circ} \mathrm{C}$ under light conditions (c) and in the darkness $(\mathbf{d})$, regrowth of shoots at optimal conditions on medium with $1.11 \mu \mathrm{M}$ BA and $0.14 \mu \mathrm{M}$ NAA after 12 months of storage under light conditions (e) and in the dark (f), rooted shoots on medium without plant regulators after storage for 12 months under light conditions (g) and in the dark (h). $\mathrm{Bar}=1 \mathrm{~cm}$
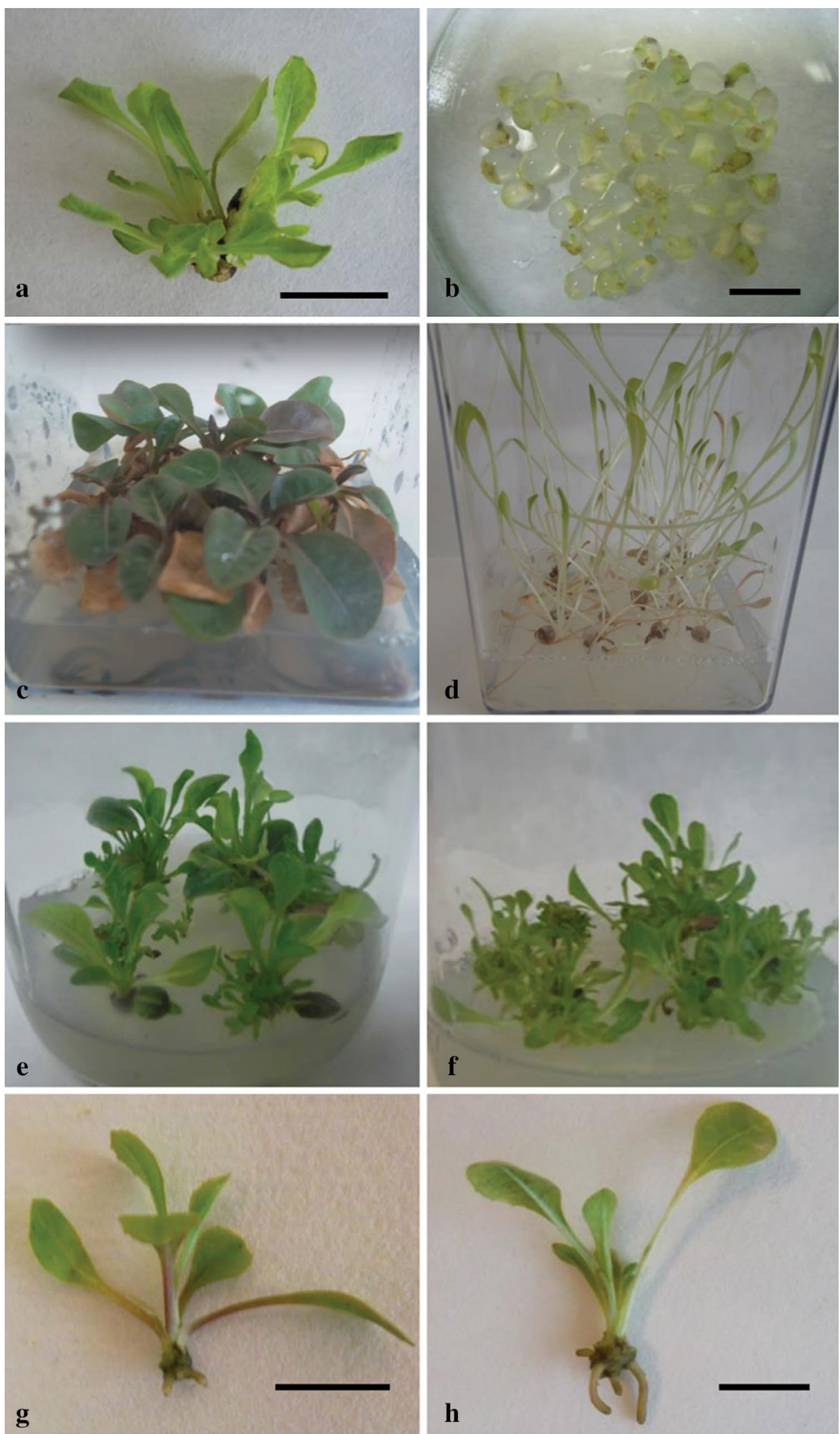
Each sample was gently mixed and incubated for $10 \mathrm{~min}$ at room temperature. Ploidy level was analyzed using a flow cytometer BD FACSAria $^{\text {TM }}$ III (BD Biosciences), which incorporates 3 air-cooled lasers at 488, 633, and $407 \mathrm{~nm}$ wavelengths, and equipped with BD FACSDiva ${ }^{\mathrm{TM}}$ software. A minimum of 10,000 events were analyzed per sample. The control sample from $T$. pieninicum (the plant conventionally cultivated in soil) was used to set the diploid gate. Data collected included one-parameter histograms of cellular fluorescent intensities.

\section{RAPD analysis}

Randomly chosen plants after acclimatization were chosen to RAPD analysis. Young leaves of plants $(125 \mathrm{mg}$ ) acclimatized after cold storage lasting 9 and 12 months were frozen in liquid nitrogen, and DNA isolation was performed using modified Doyle and Doyle (1987) methodology based on CTAB extraction buffer. Plants germinated from natural seeds and grown in pots were used as a control. The reaction mixture for PCR $(25 \mu \mathrm{l})$ contained: $1 \times$ Optimized DyNAzyme buffer (1.5 mM $\mathrm{MgCl}_{2}$ ), $200 \mu \mathrm{M}$ each dNTP, $0.5 \mu \mathrm{M}$ primer, $50 \mathrm{mg}$ DNA and 1 unit of DyNAzyme II DNA Polymerase (Fermentas). Analysis was performed using 30 oligonucleotide (decamer) primers (Table 1). PCR reactions were carried out in a thermocycler (Eppendorf AG 22331,
Hamburg, Germany) with an initial denaturation of the DNA at $94{ }^{\circ} \mathrm{C}$ for $2 \mathrm{~min}$ and then 35 cycles of amplification consisting of denaturation at $94{ }^{\circ} \mathrm{C}$ for $30 \mathrm{~s}$, primer annealing at Tm calculated for each primer for $30 \mathrm{~s}$ and primer extension at $72{ }^{\circ} \mathrm{C}$ for $2 \mathrm{~min}$. The final extension was performed at $72{ }^{\circ} \mathrm{C}$ for $7 \mathrm{~min}$. The PCR products were electrophoresed in $1 \%$ agarose gel (carried out at $100 \mathrm{~V}$ ) using $1 \times$ TBE running buffer and SYBR ${ }^{\circledR}$ Green I. The size of amplicons was visualized under UV light and estimated using DNA ladder (100-10,000 bp). Only clear and reproducible bands were taken into account in the analysis.

\section{Data collection and statistical analysis}

The microshoots were evaluated at 3 month intervals. In each variant of storage 4 replicates of 16 encapsulated shoot tips were used. Proliferation rate in 1st subculture (an average shoots formed per explant) was obtained for shoots that survived the cold treatment for 3, 6, 9 and 12 months. Proliferation rate in 2 nd subculture and rooting rate were evaluated for 12 explants in each replicate. Data were expressed as mean \pm standard error (SE). Normality of variances was verified using the Shapiro-Wilk test. To examine significant differences among the treatments Kruskal-Wallis test at $\mathrm{p} \leq 0.05$ was then performed, because of a non-normal distribution of the data in most treatments. Flow cytometry
Table 1 List of primers used for RAPD analysis with their sequences, melting temperatures, GC content and number of bands generated in PCR reaction with DNA from control and cold-stored and regrown in optimal conditions plants of Taraxacum pieninicum

\begin{tabular}{llllll}
\hline No. & Sequence $\left(5^{\prime}-3^{\prime}\right)$ & $\mathrm{T}_{\mathrm{M}}\left({ }^{\circ} \mathrm{C}\right)$ & GC content $(\%)$ & $\begin{array}{l}\text { Number of } \\
\text { bands }\end{array}$ & Band size range (bp) \\
\hline 1 & ACAAAGAACA & 26.0 & 30.0 & 1 & 800 \\
2 & TAGCATTCCT & 28.0 & 40.0 & 3 & $400-1700$ \\
3 & CAGTTTACAC & 28.0 & 40.0 & 3 & $1000-1800$ \\
4 & CTCATTCACT & 28.0 & 40.0 & 3 & $1000-1500$ \\
5 & TAAACGAGCT & 28.0 & 40.0 & 2 & $900-1000$ \\
6 & GCTCAATACT & 28.0 & 40.0 & 1 & 700 \\
7 & TAGTTCCTCT & 28.0 & 40.0 & 1 & 600 \\
8 & CCAAGCTAGA & 30.0 & 50.0 & 5 & $600-2000$ \\
9 & GGGTTTGACA & 30.0 & 50.0 & 4 & $400-2500$ \\
10 & AGGTTGCGAA & 30.0 & 50.0 & 4 & $800-3500$ \\
11 & GTACAATCCC & 30.0 & 50.0 & 2 & $1200-3000$ \\
12 & GCACAAACGA & 30.0 & 50.0 & 2 & $800-3000$ \\
13 & TGGCTGACAA & 30.0 & 50.0 & 2 & $600-900$ \\
14 & ACGTGCTACC & 32.0 & 60.0 & 5 & $400-2000$ \\
15 & TGTCGCCTAG & 32.0 & 60.0 & 5 & $800-1500$ \\
16 & ACTGGACCTC & 32.0 & 60.0 & 4 & $700-1500$ \\
17 & GCCTACACTG & 32.0 & 60.0 & 4 & $1200-3500$ \\
18 & GCCGTATGCA & 32.0 & 60.0 & 3 & $700-1500$ \\
19 & GCAGGGCTCT & 34.0 & 70.0 & 5 & $700-3000$ \\
20 & CCACTCTCCC & 34.0 & 70.0 & 5 & $700-2000$ \\
21 & ACCGACGCAC & 34.0 & 70.0 & Total & $600-1200$ \\
& & & & 5 & \\
\hline & & & 5 &
\end{tabular}


analyses were carried out in three replicates of the independent plants, while RAPD were performed for three random plants in two independent analyses.

\section{Results}

\section{The survival and visual rates of cold-stored explants}

Synthetic seeds of $T$. pieninicum showed high visual rate immediately after encapsulation but shoot tips lost their viability over time under optimal conditions. Non-stored synseeds were able to conversion into the whole plant only in $46.7 \pm 4.5 \%$ (Fig. 2). However, cold-storage regardless of the duration increased survival by stimulation of the conversion and it was reported that from 70.0 to $96.7 \%$ of synseeds were able to develop into plantlets. Survival was not statistically significant affected by storage time and light conditions during cold treatment.

Plants obtained from non-stored synthetic seeds given a visual rating of 5 , based on Reed's scale, but decreasing with the duration of storage (Fig. 3). At light conditions this value decreased significantly in the following months up to the value of $1.7 \pm 0.2$ after 12 months of cold-storage (Figs. 1c, 3 ). Whereas condition of plants converted from synseeds stored in darkness was rated at $3.8 \pm 0.2$ and prolonged storage did not significantly influence this value (Figs. 1d, 3).

\section{Regrowth of cold stored shoots}

Shoots after storage at $4{ }^{\circ} \mathrm{C}$ for $3,6,9$ and 12 months in dark and at light conditions were regrown in optimal growth conditions on MS medium supplemented with $1.1 \mu \mathrm{M}$ BA and $0.14 \mu \mathrm{M}$ NAA. Storage at light conditions decreased shoot

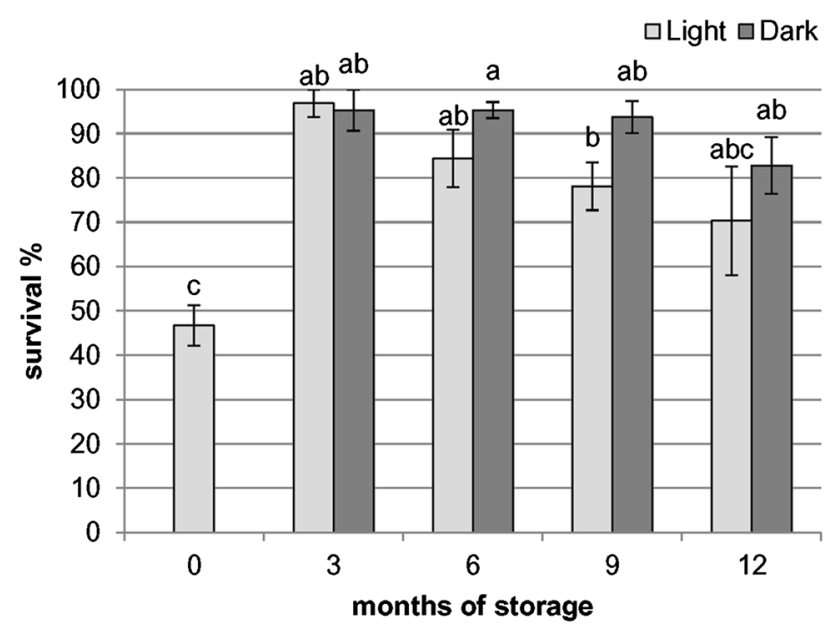

Fig. 2 Survival rate of shoots after cold-storage. Control were nonstored synthetic seeds

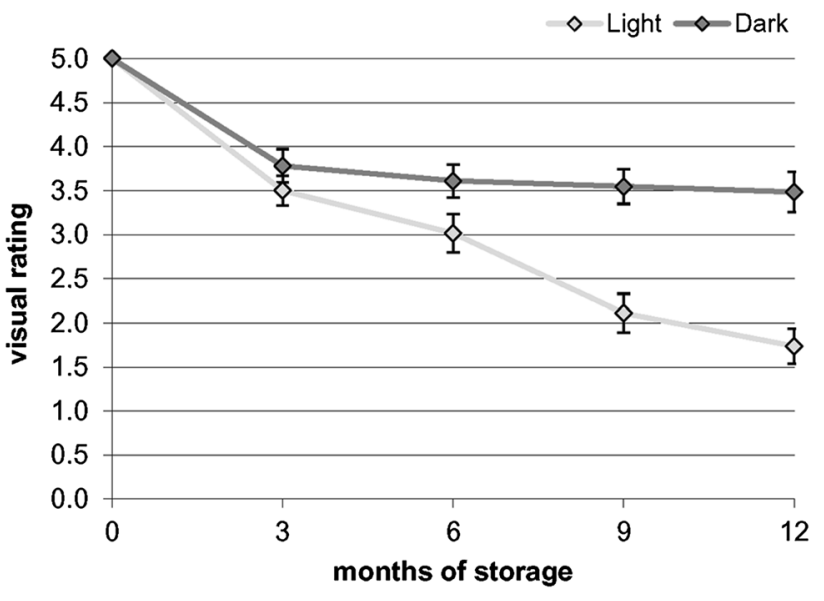

Fig. 3 The effect of light conditions and time of storage on the visual rating of Taraxacum pieninicum shoots converted during storage as synthetic seeds

tips ability to proliferate in first subculture, regardless of the length of storage period (Figs. 1e, 4a) and the differences were statistically significant to control. Proliferation was not affected by storage in the dark and the number of shoots per explant ranged from $14.8 \pm 1.3$ (after 3 months) to $12.2 \pm 1.2$ (after 12 months) and was comparable to the control, where $12.3 \pm 0.8$ shoots per explant were noted (Figs. 1f, $4 a$ ). Significant differences were noted between storage under light and in dark after each time of storage.

In the second subculture, lower proliferation rates compared to non-chilled were recorded only for 3 months storage and 6 months under light conditions (Fig. 4b), differences were statistically significant. Proliferation ability of shoot tips stored for 6 months in the dark and longer (regardless of the storage duration and the light conditions) was comparable with control plants. After 12 months of cold treatment under light and in the dark proliferation rate was $18.5 \pm 1.5$ and $17.2 \pm 1.2$ shoots per explant, respectively.

Shoots obtained in 2nd subculture of regrowth were able to root (Fig. 5). The number of roots per shoot ranged from $0.9 \pm 0.2$ to $1.9 \pm 0.2$ and the differences were not statistically significant in compare to results obtained for the control variants except shoots after storage in the dark for 3 months. All rooted shoots were acclimatized to ex vitro conditions, $100 \%$ of plantlets survived transfer to field conditions.

\section{Flow cytometry and RAPD analysis}

The DNA content of the plants stored for 9 and 12 months at $4{ }^{\circ} \mathrm{C}$ was measured by flow cytometry to determine the ploidy level in plant material after cold storage. Leaves of control plants have a 2C DNA (G0/G1 phase) and 4C DNA ( $\mathrm{G} 2$ phase of cells divisions). The results indicated that plants regenerated following the longest time of storage had 


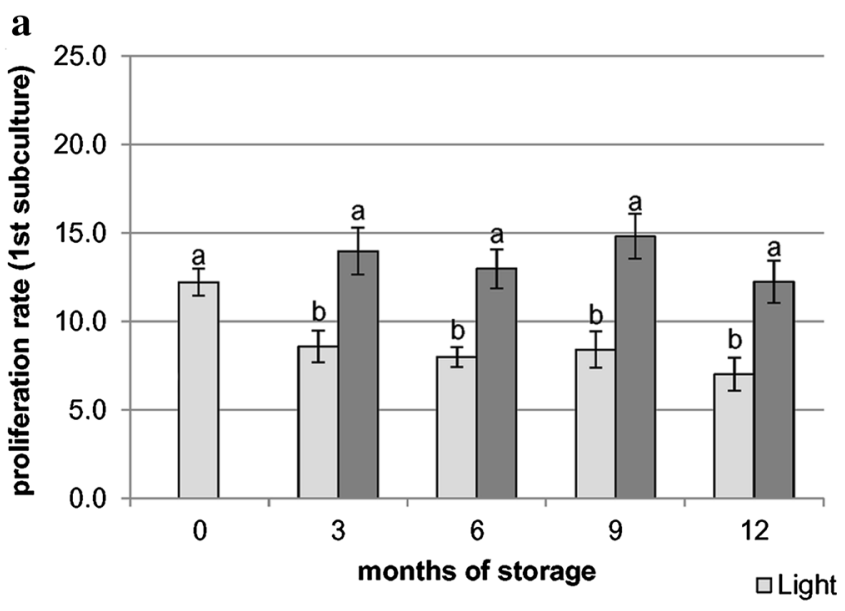

Fig. 4 The effect of light conditions and duration of Taraxacum pieninicum storage at $4{ }^{\circ} \mathrm{C}$ on the proliferation rate of shoots during regrowth on medium with $1.11 \mu \mathrm{M} \mathrm{BA}$ and $0.14 \mu \mathrm{M}$ NAA in the 1 st

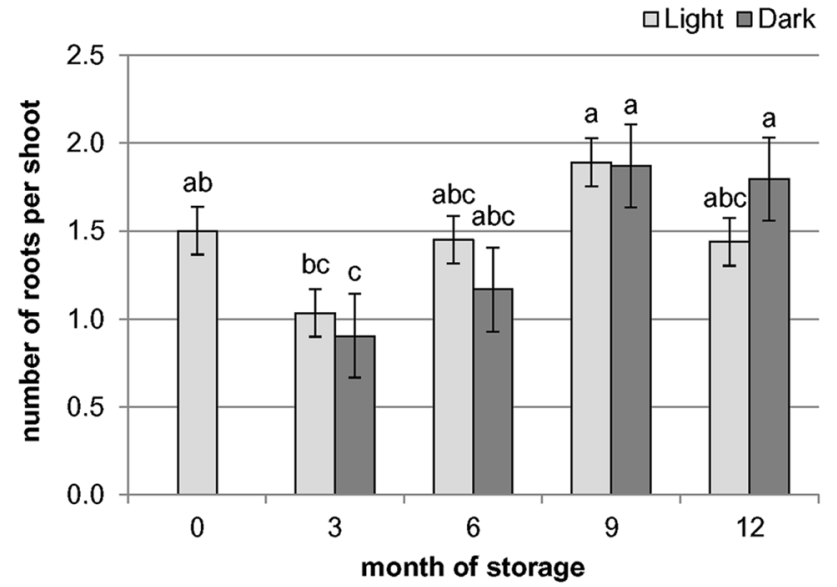

Fig. 5 The effect of light conditions and duration of storage at $4{ }^{\circ} \mathrm{C}$ on rooting of Taraxacum pieninicum shoots after regrowth. Means with different letters are significantly different followed by KruskalWallis test at $\mathrm{p} \leq 0.05$

the same ploidy level as control plants, independently of the light conditions (Fig. 6), so it can be concluded that slowing down and speeding up metabolism of T. pieninicum during cold-storage and regrowth, respectively, did not interfere with cell division. Furthermore, RAPD analysis was performed to verify the genetic stability of regrown plantlets after cold storage. In the initial screening 30 primers were used with the DNA of control plants and 21 primers were selected for further analysis. The 21 RAPD primers used yielded 67 scorable bands (Table 1). The size of amplified fragments ranged from 600 to $3000 \mathrm{bp}$. All regenerants from encapsulated and stored shoot tips were genetically similar to the plants non-cultured, cultivated in conventional conditions in pots. Examples of RAPD amplifications are shown b

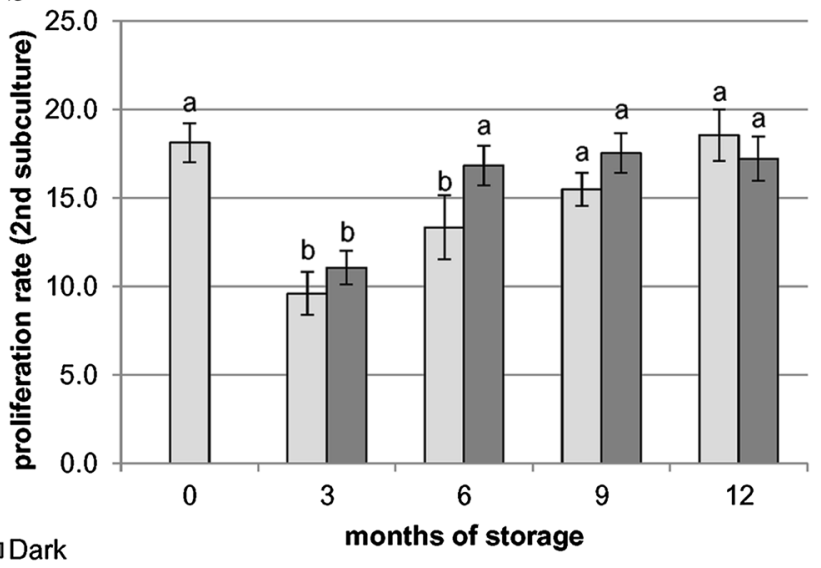

(a) and 2nd subculture (b). Means with different letters are significantly different followed by Kruskal-Wallis test at $\mathrm{p} \leq 0.05$

in Fig. 7, representing band patterns obtained with primers No. 16 and 19.

\section{Discussion}

The relatively low conversion rate of control plants (noncold stored) can refer to the conditions prevailing in the natural environmental of this species. Seeds of many alpine species have mechanisms that protect seeds from germination in autumn (Graae et al. 2008). The most prevalent mechanism is physiological dormancy, resulting from the high abscisic acid (ABA):gibberellic acid (GA) ratio in embryo tissue. Such seeds require stratification, which reduces the ABA concentration, stimulates synthesis of GA and thus enables germination (Finch-Savage and Leubner-Metzger 2006). Cold storage of T. pieninicum was preceded by encapsulation of shoot tips isolated from the cluster, but the isolation and preparation of artificial seeds were stress factors that probably led to ABA synthesis in isolated tissue, which inhibited the conversion of synseeds after direct transfer to optimal conditions. Low temperature during storage stimulates ABA (Kamińska et al. 2016) and GA biosynthesis (Yamauchi et al. 2004). However, on the basis of our results we can presume that light during storage is more stressful than darkness and leads to greater increase in ABA level and thereby to increase the ABA:GA ratio. In darkness the supposed lower ABA:GA ratio might increase survival and proliferation rate of stored synseeds. Similar results were obtained with kiwifruit synthetic seeds, where cold treatment given to encapsulated apical and axillary buds increased their viability and regrowth comparing to non-cold stored synseeds (Adriani et al. 2010). 
Cold is the simplest and most efficient method to slow in vitro growth. According to most studies, storage at $4{ }^{\circ} \mathrm{C}$ is most suitable for many species. In the case of Dalbergia sissoo storage lasted 4 weeks (Chand and Singh 2004), Quercus robur and Quercus cerris 6 weeks (Tsvetkov and Hausman 2005), Eclipta alba and Withania somnifera 8 weeks (Singh et al. 2006, 2010). In this paper synseeds were successfully stored even for 12 months, as in the case of shoot apices of Pistacia vera encapsulated with addition of sucrose in artificial endosperm. Similarly as in that study better condition of plants was observed after 9 and 12 months of storage at $4{ }^{\circ} \mathrm{C}$ in comparison to 3 and 6 months. It could be due to adaptation of microshoots to low-temperature conditions (Akdemir et al. 2013).

Synseeds storage in dark was more suitable on the basis of our results of survival, visual and proliferation rate. The same result was obtained for storage of T. pieninicum shoot tips without alginate coat (Kamińska et al. 2016). However, alginate coat improved conditions of the stored plants, what was manifested by better visual rating of the stored material compared to non-capsulated, confirming the protective role of the artificial seed structure. The value of proliferation rate, despite the prolonged storage period to 1 year, remained stable in the dark, indicating the possibility of further extending the cold-storage of the synseeds. Similarly, Mallus sp. rootstocks (Orlikowska 1992), Prunus armeniac shoot tips (Pérez-Tornero et al. 1999), rootstocks of different species of Prunus (Marino et al. 1985) were best preserved in the dark. Necrosis and browning observed during cold storage under light conditions were less pronounced in darkness in Populus tremula $\times$ Populus tremuloides shoots (Hausman et al. 1994) and Quercus suber shoots (Romano and MartinsLoução 1999). Adaptation to cold and to the presence or absence of light is also genotype-dependent. Storage at $4{ }^{\circ} \mathrm{C}$ in darkness was effective for plum genotypes like cv. Ariddu di Core and Sanacore but less so for the cv. Marabolo and Rapparino varieties (Gianní and Sottile 2015). Darkness had a positive effect on the regrowth of the Vitis berlandieri $\times V$. riparia after 3,6 , and 9 months of $4{ }^{\circ} \mathrm{C}$ storage in alginate beads (Benelli 2016).

A major problem in in vitro culture is the possibility of the occurrence of somaclonal variation that can result in obtaining different clones from the mother plant. In this study flow cytometry analysis was performed due to the fact that slow-growth storage and further regrowth on MS medium supplemented with BA may lead to abnormalities that change the amount of DNA in the cells. However, our results indicated that all the regenerants had the same ploidy level, irrespective of the storage treatment. The same results were obtained for shoot tips cold-stored for 9 months without artificial seed covering (Kamińska et al. 2016). Similarly Skene et al. (1988) reported that storage at $9.5^{\circ} \mathrm{C}$ of multiple shoot cultures of eight Vitis genotypes for over 12 months did not affect the ploidy level of regenerated plants. Ploidy variations such as mixoploidy or poliploidy were reported in long term callus and somatic embryo cultures (Endemann et al. 2001).

Our results also showed that the storage does not produce genetic variation at the resolution provided by the RAPD analysis with 21 randomly primers. This research is consistent with reports of genetic stability (RAPD) of stored synthetic seed derived plants of Ananus comosus after 2 months at $8{ }^{\circ} \mathrm{C}$ (Gangopadhyay et al. 2005), Cineraria maritime after 6 months at $25 \pm 2{ }^{\circ} \mathrm{C}$ (Srivastava et al. 2009), Cannabis sativa after 6 months at 5,15 and $25^{\circ} \mathrm{C}$ (Lata et al. 2011), Picrorhiza kurrooa after 3 months at $25 \pm 2{ }^{\circ} \mathrm{C}$ (Mishra et al. 2011), Glycyrrhiza glabra after 6 months at $25 \pm 2{ }^{\circ} \mathrm{C}$ (Mehrotra et al. 2012) and Ocimum kilimandscharicum after 3 months at 4 and $25^{\circ} \mathrm{C}$ (Saha et al. 2015). Hao and Deng (2003) noted that AFLP assay found no genetic variations between non-stored and stored at $4{ }^{\circ} \mathrm{C}$ for 1 year shoot tips of Malus pumila cv. Gala. However, slow growth storage resulted in a significant DNA methylation changes. In contrast, high propability of genetic instability was observed after 12 months of storage at $4^{\circ}$ of Pistacia lentiscus (Koç et al. 2014).

It is considered that the axillary buds and shoot tips are the most stable genetically. In turn, high probability of genetic change occurs in callus and protoplast culture (Krishna et al. 2016). However, irrespective of the source of plant material, somaclonal variation cannot be excluded, as it was demonstrated in study on Camellia sinensis and $C$. assamica, in which organized meristem cultures were not always genetically true-to-type (Devarumath et al. 2002). Also Evans (1988) reported considerable variation in adventitious Nicotiana alata plants regenerated directly from leaf explants without a callus intermediate. Although in cold storage growth of the explants is slowed down, prolonged exposure to low temperature may cause stress especially to thermophilic species. Generation of reactive oxygen species (ROS) during exposure to cold stress can also lead to somaclonal variation (Cassells and Curry 2001).

\section{Conclusion}

This is the first report of genetically sustainable synseeds production of T. pieninicum using shoot tips. Applied conditions provide a promising, cost-effective and time-saving method for an active protection of this species. Successful plant retrieval from synseeds following 12-months storage at $4{ }^{\circ} \mathrm{C}$ indicates that protocol described in this paper could be used to long-term preservation of the T. pieninicum germplasm. The protocol described here could also serve as a first step for optimization of in vitro conservation of other endangered species from Asteraceae family. 

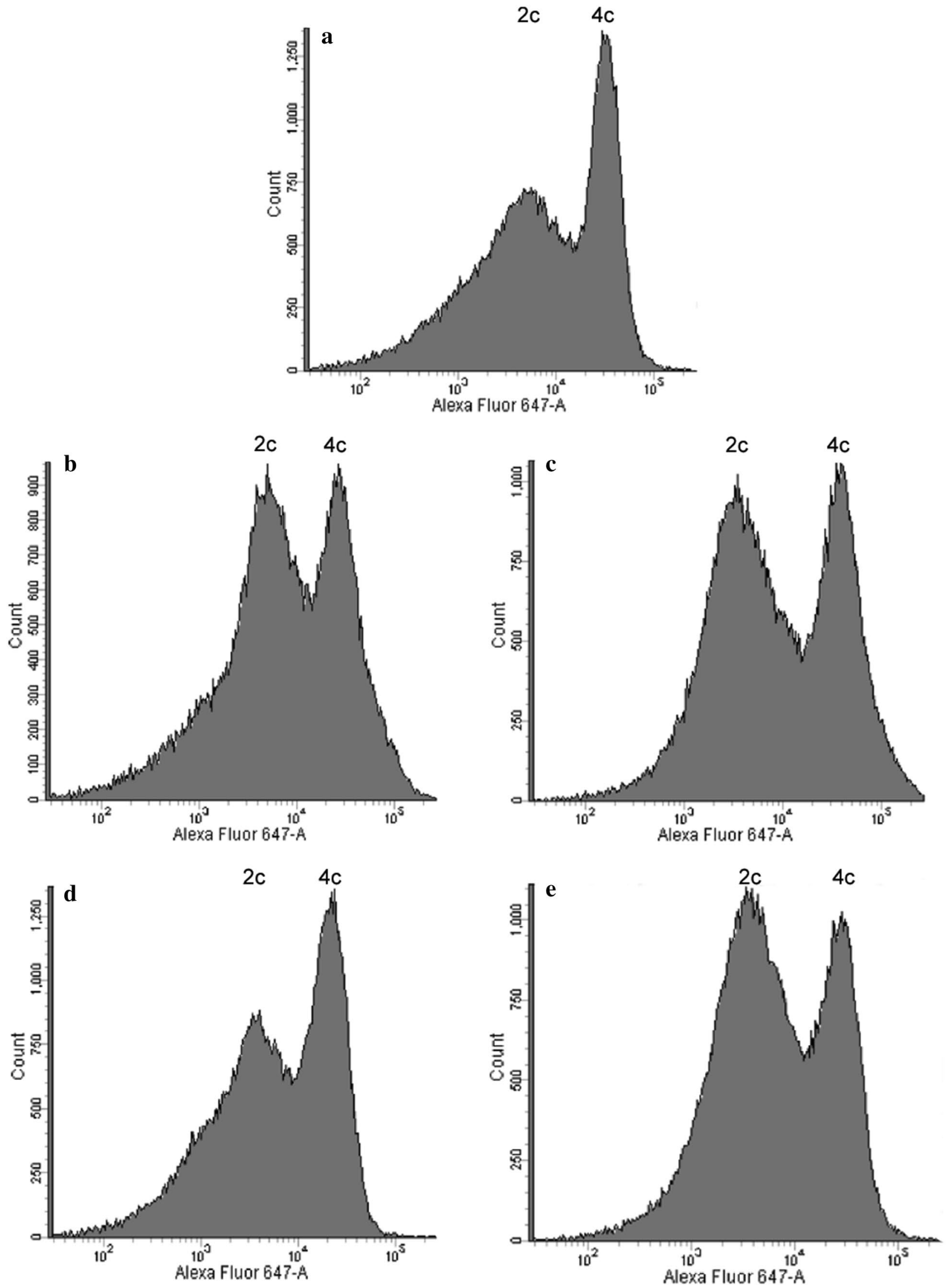
4Fig. 6 Flow cytometry histograms of Taraxacum pieninicum after storage at $4{ }^{\circ} \mathrm{C}$, regrowth at optimal conditions on medium with $1.11 \mu \mathrm{M}$ BA and $0.14 \mu \mathrm{M}$ NAA and acclimatization: control plant (non-stored, conventionally cultivated in soil) (a), plant obtained after 9 months of storage under light conditions (b), in the dark (c) and after 12 months under light conditions (d) and in the dark (e)

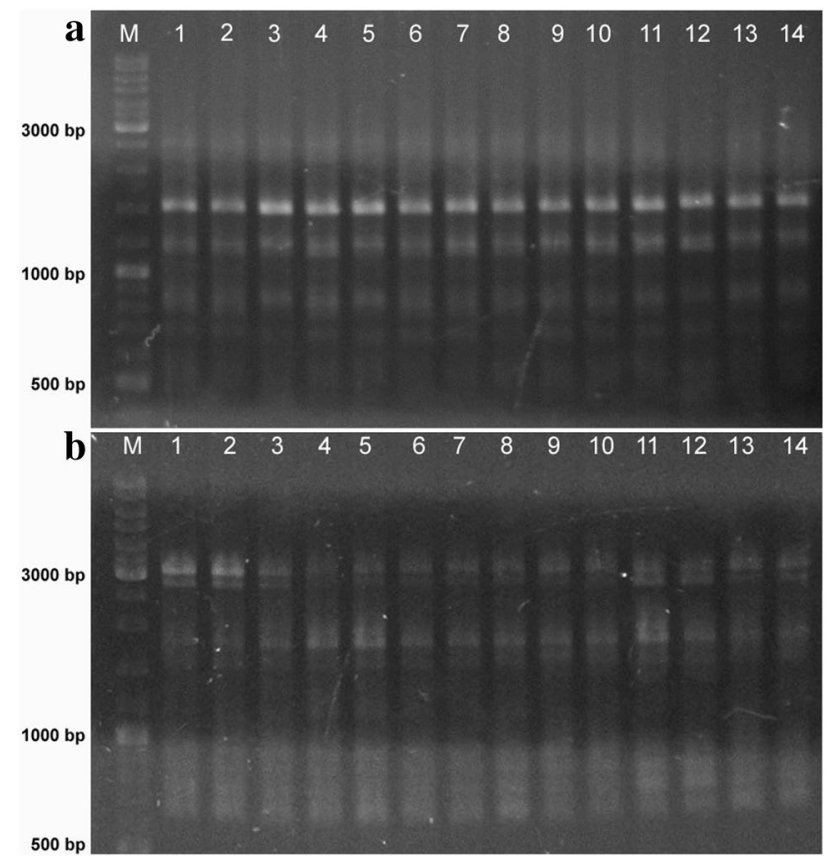

Fig. 7 Results of agarose gel electrophoresis of PCR amplification with primers No. 16 (a) and 19 (b) and DNA of Taraxacum pieninicum plantlets regrown after cold-storage: molecular marker (100$10,000 \mathrm{bp}$ ) (M), control plants (non-stored, conventionally cultivated in soil) (lines 1-2), plants stored for 9 months under light conditions (lines 3-5), in the dark (lines 6-8), and for 12 months under light conditions (lines 9-11) and in the dark (12-14)

Acknowledgements This project was supported by funds provided by Nicolaus Copernicus University (Toruń, Poland) for the research programme of the Chair of Plant Physiology and Biotechnology.

Author contributions MK designed and carried out all the experiments, analysed the data and wrote the manuscript, AT designed the experiments and carried out an analysis of the flow cytometer, analysed the data and wrote the manuscript, MG helped in analysis of the flow cytometer, and AT helped in RAPD analysis.

\section{Compliance with ethical standards}

Conflict of interest The authors declare that they have no conflict of interest.

Open Access This article is distributed under the terms of the Creative Commons Attribution 4.0 International License (http://creativecommons.org/licenses/by/4.0/), which permits unrestricted use, distribution, and reproduction in any medium, provided you give appropriate credit to the original author(s) and the source, provide a link to the Creative Commons license, and indicate if changes were made.

\section{References}

Adriani M, Piccioni E, Standardi A (2010) Effect of different treatments on the conversion of 'Hayward' kiwifruit synthetic seeds to whole plants following encapsulation of in vitro-derived buds. N Z J Crop Hortic Sci 28:59-67. https://doi.org/10.1080/01140 671.2000.9514123

Ahmed MR, Anis M, Al-Etta HA (2015) Encapsulation technology for short-term storage and germplasm exchange of Vitex trifolia L. Rend Fis Acc Lincei 26:133-139. https://doi.org/10.1007/ s12210-014-0366-1

Akdemir H, Süzerer V, Tilkat E, Yildirim H, Onay A, Çiftçi YO (2013) In vitro conservation and cryopreservation of mature pistachio (Pistacia vera L.) germplasm. J Plant Biochem Biotechnol 22:4351. https://doi.org/10.1007/s13562-012-0109-2

Ara H, Jaiswal U, Jaiswal VS (1999) Germination and plantlet regeneration from encapsulated somatic embryo of mango (Mangifera indica L.). Plant Cell Rep 19:166-170. https://doi.org/10.1007/ s002990050728

Benelli C (2016) Encapsulation of shoot tips and nodal segments for in vitro storage of "Kober 5BB" grapevine rootstock. Horticulturae 2:10. https://doi.org/10.3390/horticulturae2030010

Bordallo PN, Silva DH, Maria J, Cruz CD, Fontes EP (2004) Somaclonal variation on in vitro callus culture potato cultivars. Hortic Bras 22:300-304. https://doi.org/10.1590/ S0102-05362004000200027

Cassells AC, Curry RF (2001) Oxidative stress and physiological, epigenetic and genetic variability in plant tissue culture: implications for micropropagators and genetic engineers. Plant Cell Tissue Organ Cult 64:145-167. https://doi.org/10.102 3/A:1010692104861

Chand S, Singh AK (2004) Plant regeneration from encapsulated nodal segments of Dalbergia sissoo Roxb.- a timber yielding leguminous tree. J Plant Physiol 161:237-243. https://doi. org/10.1078/0176-1617-01036

Cruz-Cruz CA, González-Arnao MT, Engelmann F (2013) Biotechnology and conservation of plant biodiversity. Resources 2:73-95. https://doi.org/10.3390/resources2020073

Currais L, Loureiro J, Santos C, Canhoto JM. Ploidy stability in embryogenic cultures and regenerated plantlets of tamarillo. Plant Cell Tissue Organ Cult. 114:149-159. https://doi.org/10.1007/ s11240-013-0311-5

Devarumath RM, Nandy S, Rani V, Marimuthu S, Muraleedharan N, Raina SN (2002) RAPD, ISSR and RFLP fingerprints as useful markers to evaluate genetic integrity of micropropagated plants of three diploid and triploid elite tea clones representing Camellia sinensis (China type) and C. assamica ssp. assamica (AssamIndia type). Plant Cell Rep 21:166-173. https://doi.org/10.1007/ s00299-002-0496-2

Doyle JJ, Doyle JL (1987) A rapid DNA isolation procedure for small quantities of fresh leaf tissue. Phytochem Bull 19:11-15

Endemann M, Hristoforoglu K, Stauber T, Wilhelm E (2001) Assesment of age- related polyploidy in Quercus robur L. somatic embryos and regenerated plants using DNA flow cytometry. Biol Plant 44:339-345. https://doi.org/10.1023/A:1012426306493

Engelmann F (2011) Use of biotechnologies for the conservation of plant biodiversity. In Vitro Cell Dev Biol Plant 47:5. https://doi. org/10.1007/s11627-010-9327-2

Evans DA (1988) Applications of somaclonal variation. In: Mizrahi A (ed) Biotechnology in agriculture. Alan R. Liss Inc, New York, pp 203-223. https://doi.org/10.1016/0168-9525(89)90021-8

Finch-Savage WE, Leubner-Metzger G (2006) Seed dormancy and the control of germination. New Phytol 171:501-523. https://doi. org/10.1111/j.1469-8137.2006.01787.x 
Galbraith DW, Harkins KR, Maddox JM, Ayres NM, Sharma DP, Firoozabady E (1983) Rapid flow cytometric analysis of the cell cycle in intact plant tissues. Science 220:1049-1051. https://doi. org/10.1126/science.220.4601.1049

Gangopadhyay G, Bandyopadhyay T, Poddar R, Gangopadhyay SB, Mukherjee KK (2005) Encapsulation of pineapple micro shoots in alginate beads for temporary storage. Curr Sci 88:972-977

Gianní S, Sottile F (2015) In vitro storage of plum germplasm by slow growth. HortScience 42:61-69. https://doi. org/10.17221/186/2014-HORTSCI

Graae BJ, Alsos IG, Ejrnaes R (2008) The impact of temperature regimes on development, dormancy breaking and germination of dwarf shrub seeds from arctic, alpine and boreal sites. Plant Ecol 198:275-284. https://doi.org/10.1007/s11258-008-9403-4

Hao YJ, Deng XX (2003) Genetically stable regeneration of apple plants from slow growth. Plant Cell Tissue Organ Cult 72:253260. https://doi.org/10.1023/A:1022388728497

Hausman JF, Neys O, Kevers C, Gaspar T (1994) Effect of in vitro storage at $4{ }^{\circ} \mathrm{C}$ on survival and proliferation of poplar shoots. Plant Cell Tissue Organ Cult 38:65-67. https://doi.org/10.1007/ BF00034446

Honek A, Martinkova Z, Saska P (2005) Post-dispersal predation of taraxacum officinale (dandelion) seed. J Ecol 93:345-352. https:// doi.org/10.1111/j.1365-2745.2005.00987.x

IUCN (2017) IUCN red list of threatened species. http://www.iucnredlist.org

Jin S, Mushke R, Zhu H, Tu L, Lin Z, Zhang Y, Zhang X (2008) Detection of somaclonal variation of cotton (Gossypium hirsutum) using cytogenetics, flow cytometry and molecular markers. Plant Cell Rep 27:1303-1316. https://doi.org/10.1007/s00299-008-0557-2

Kamińska M, Skrzpek E, Wilmowicz E, Tretyn A, Trejgell A (2016) Effect of light conditions and ABA on cold storage and post-storage propagation of Taraxacum pieninicum. Plant Cell Tissue Organ Cult 127:25-34. https://doi.org/10.1007/ s11240-016-1026-1

Koç İ, Akdemir H, Onay A, Çiftçi Y (2014) Cold-induced genetic instability in micropropagated Pistacia lentiscus L. plantlets. Acta Physiol Plant 36:2373-2384. https://doi.org/10.1007/ s11738-014-1610-0

Krishna H, Alizadeh M, Singh D, Singh U, Chauhan N, Eftekhari M, Sadh RK (2016) Somaclonal variations and their applications in horticultural crops improvement. 3 Biotech 6:54. https://doi. org/10.1007/s13205-016-0389-7

Kula A, Grabowska-Joachimiak A, Kasjaniuk M, Legutko J, Marciniuk P, Musiał K (2013) Chromosome numbers in 10 Taraxacum species from Poland. Acta Biol Cracov Ser Bot 55:153-157. https:// doi.org/10.2478/abcsb-2013-0030

Lata H, Chandra S, Techen N, Khan IA, ElSohly MA (2011) Molecular analysis of genetic fidelity in Cannabis sativa L. plants grown from synthetic (encapsulated) seeds following in vitro storage. Biotechnol Lett 33:2503-2508. https://doi.org/10.1007/ s10529-011-0712-7

Małecka J (1961) Studies in the mode of reproduction of the diploid endemic species Taraxacum pieninicum Pawł. Acta Biol Cracov Ser Bot 4:25-46

Marino G, Rosati P, Sagrati F (1985) Storage of in vitro cultures of Prunus rootstocks. Plant Cell Tissue Organ Cult 5:73-78. https:// doi.org/10.1007/BF00033572

Mehrotra S, Khwaja O, Kukreja AK, Rahman L (2012) ISSR and RAPD based evaluation of genetic stability of encapsulated micro shoots of Glycyrrhiza glabra following 6 months of storage. Mol Biotechnol 52:262-268. https://doi.org/10.1007/ s12033-011-9491-6

Mishra J, Singh M, Palni LMS, Nandi SK (2011) Assessment of genetic fidelity of encapsulated microshoots of Picrorhiza kurrooa. Plant
Cell Tissue Organ Cult 104:181-186. https://doi.org/10.1007/ s11240-010-9816-3

Orlikowska T (1992) Effect of in vitro storage at $4{ }^{\circ} \mathrm{C}$ on survival and proliferation of two apple rootstocks. Plant Cell Tissue Organ Cult 31:1-7. https://doi.org/10.1007/BF00043468

Pérez G, Mbogholi A, Sagarra F, Aragón C, González J, Isidrón M, Lorenzo JC (2011) Morphological and physiological characterization of two new pineapple somaclones derived from in vitro culture. In Vitro Cell Dev Biol Plant 47:428-433. https://doi. org/10.1007/s11627-011-9342-y

Pérez-Tornero O, Ortin-Parraga F, Egea J, Burgos L (1999) Mediumterm storage of apricot shoot tips in vitro minima growth methods. HortScience 34:1277-1278

Reed BM (1992) Cold storage of strawberries in vitro: a comparison of three storage systems. Fruit Var J 46:98-102

Romano A, Martins-Loução MA (1999) In vitro cold storage of cork oak shoot cultures. Plant Cell Tissue Organ Cult 59:155-157. https://doi.org/10.1023/A:1006465706905

Saha S, Sengupta C, Ghosh P (2015) Encapsulation, short-term storage, conservation and molecular analysis to assess genetic stability in alginate-encapsulated microshoots of Ocimum kilimandscharicum Guerke. Plant Cell Tissue Organ Cult 120:519-530. https://doi. org/10.1007/s11240-014-0618-x

Singh AK, Varshney R, Sharma M, Agarwal SS, Bansal KC (2006) Regeneration of plants from alginate-encapsulated shoot tips of Withania somnifera (L.) Dunal, a medicinally important plant species. J Plant Physiol 163:220-223. https://doi.org/10.1016/j. jplph.2005.06.013

Singh SK, Rai MK, Asthana P, Sahoo L (2010) Alginate-encapsulation of nodal segments for propagation, short-term conservation and germplasm exchange and distribution of Eclipta alba (L.). Acta Physiol Plant 32(3):607-610. https://doi.org/10.1007/ s11738-009-0444-7

Skene KGM, Goodwins DR, Barlass M (1988) Ploidy stability in grapevines following long term storage in vitro. Vitis 27:41-46

Srivastava V, Khan SA, Banerjee S (2009) An evaluation of genetic fidelity of encapsulated microshoots of the medicinal plant: Cineraria maritime following six months of storage. Plant Cell Tissue Organ Cult 99:193-198. https://doi.org/10.1007/ s11240-009-9593-z

Tas IC, Van Dijk PJ (1999) Crosses between sexual and apomictic dandelions (Taraxacum). I. The inheritance of apomixis. Heredity 83:707-714. https://doi.org/10.1046/j.1365-2540.1999.00619.x

Trejgell A, Chernetskyy M, Podlasiak J, Tretyn A (2013) An efficient system for regenerating Taraxacum pieninicum Pawł. from seedling explants. Acta Biol Cracov Ser Bot 55:73-79. https://doi. org/10.2478/abcsb-2013-00013

Trejgell A, Kamińska M, Tretyn A (2015) In vitro slow growth storage of Senecio macrophyllus shoots. Acta Physiol Plant 37:234. https://doi.org/10.1007/s11738-015-1983-8

Tsvetkov I, Hausman JF (2005) In vitro regeneration from alginateencapsulated microcuttings of Quercus sp. Sci Hort 103:503-507. https://doi.org/10.1016/j.scienta.2004.06.013

Yaacob JS, Loh HS, Taha RM (2013) Protein profiling and histone deacylation activities in somaclonal variants of oil palm (Elaeis guineensis Jacq.). Sci World J 2013:1-8. https://doi. org/10.1155/2013/613635

Yamauchi Y, Ogawa M, Kuwahara A, Hanada A, Kamiya Y, Yamaguchi S (2004) Activation of gibberellin biosynthesis and response pathways by low temperature during imbibition of Arabidopsis thaliana seeds. Plant Cell 16:367-378. https://doi.org/10.1105/ tpc. 018143 